\title{
Online Learning in Schools of Business: The Impact of Strategy on Course Enrollments
}

\author{
Maureen Snow Andrade \\ Utah Valley University \\ Ronald Mellado Miller \\ Utah Valley University \\ Michelle B. Kunz \\ Morehead State University \\ Janet M. Ratliff \\ Morehead State University
}

\begin{abstract}
Online education in schools of business is an ongoing, emerging practice. Strategic planning by institutions and programs seeks to identify the most relevant factors in providing the most effective online learning for students. This requires that schools of business figure out what factors positively and directly affect course enrollments. This research study surveyed deans of AACSB-accredited business schools to determine their online learning strategies and practices. The results of the survey and study support online education as a means to meet the increasing needs of a diverse and ever-changing student population both now and in the future.
\end{abstract}

Keywords: Online Education, Schools of Business, Student Enrollment, Strategic Planning

\section{INTRODUCTION}

Higher education benefits individuals, families, communities, and nations (Ma, Pender, \& Welch, 2016). Consequently, movements to widen access are occurring globally, particularly in countries that have traditionally had elitist post-secondary education systems (Evans, Rees, Taylor, \& Wright, 2017). This is resulting in increased demand and new populations of learners. Worldwide, 414.2 million students are expected to participate in higher education by 2030 compared to 99.4 million in 2000 (Ossiannilsson, Williams, Camilleri, \& Brown, 2015). In the United States, 38\% of students are over age 25, 58\% work while in college, and $26 \%$ are raising children (Lumina Foundation, n. d.). Of those who are employed, $40 \%$ work 30 or more hours a week and $25 \%$ work full-time and attend college full-time (Carnevale, Smith, Melton, \& Price, 2015). Innovative approaches to teaching and learning are required to help these learners accomplish their goals. 
Indeed, "how, where and when students learn, [and] how institutions structure programmes and services . . . are global challenges" (Ossiannilsson et al., 2015, p. 6). Since its beginnings, the purpose of distance learning has been to make "knowledge accessible to more than just a privileged few" (Kentnor, 2015 , p. 30). Generally in the form of online learning, distance learning is often viewed as a viable option to provide today's learners with needed flexibility. It expands educational access, particularly for those needing to balance study, work, and family, and enables institutions to expand their outreach (Andrade, 2016; Côté \& Allahar, 2011; Roe, Toma, Yallapragada, \& Mohan, 2015). Convenience may be why working students value online learning more than traditional students (Albert \& Johnson, 2011). However, although the number of students taking online courses has been steadily increasing, concentrations of online enrollments in public institutions, approximately $73 \%$ of all higher education enrollments in the U.S., remain relatively low (Seaman, Allen, \& Seaman, 2018).

Schools of business are well-positioned to lead educational innovation in response to the challenges and opportunities associated with widening access and changing student demographics. Business is the top choice of major for students in the U.S., Canada, Australia, and the UK (Australian Bureau of Statistics, 2017; Higher Education Statistics Agency, 2018; National Center for Educational Statistics, 2018; Statistica, 2018). This demand for business education, accompanied by students' need for flexibility in "pace, place and mode of delivery" (Higher Education Academy, 2015, para 1), has led to the development and implementation of online courses and programs within business schools. However, specific information about the strategies and successes of these initiatives is largely unknown. The purpose of this study was to gain a greater understanding of online business education strategy, and specifically the impact of current practice on online enrollments.

\section{LITERATURE REVIEW}

Some view online learning as the foundation for higher education transformation. In spite of wellpublicized reports of its growth, it has actually occurred on a limited basis - public universities, community colleges, and some for-profits, and often for only a subset of students; private liberal arts institutions are largely ignoring online education or viewing it as peripheral to mainstream offerings (Picciano, Seaman, \& Allen, 2010). "For an overall transformation to occur in American higher education online education will need to be embraced by the full range of institutions . . . . there needs to be a cultural shift in pedagogical approaches that takes advantage of the newer online technologies. Only then can widespread transformation occur" (Picciano et al., 2010, p. 32). Such a transformation indicates the need for effective leadership and strategy.

Institutional leaders responsible for distance education have identified three strategic goals: grow institutional enrollments above existing levels, promote instructional innovation, and promote student engagement (Fredericksen, 2017). These represent the pedagogical shifts needed for transformation in online learning, and particularly its effectiveness. Others have identified cost and convenience as primary motivations for the expansion of online learning as the Internet allows for scalable delivery of instructional materials (McPherson \& Baccow, 2015). This is appealing in contexts where institutions are trying to meet demand or even increase demand to be competitive and increase enrollments (leaders at public institutions in particular are concerned with increasing competition especially at a regional level), (Garrett, Legon, \& Fredericksen, 2019), but perhaps does not reflect a broad, visionary, transformational approach.

Institutional responsibilities for online learning include determining standards for development, design, and delivery; the provision of technology to effectively deliver courses (Institute of Higher Education Policy, 2000); providing faculty with appropriate professional development (Community College Research Center, 2013; Lenert \& Janes, 2017); and regular review and improvement of courses (Lenert \& Janes, 2017). These responsibilities must be directed at faculty weaknesses (as identified in a SWOT analysis conducted by de los Santos \& Zanca, 2018). Weaknesses include mastering and continually upgrading new technologies and pedagogies, gaining familiarity with design standards, and ongoing course refinement, all of which can intimidate those new to online teaching. Training has been 
found to result in faculty redesigning their courses whereas those who do not receive training tend to simply record and post their lectures online (Dumont \& Raggo, 2018).

These issues appear to be understood by institutional leaders whose top priorities for online learning, according to one report, are strategic planning, faculty development and training, and instructional design and support staff (Fredericksen, 2017). Priorities must address faculty concerns with online learning such as lack of personal interaction, student engagement, and training; increased time commitment; the need for on-going course updates; resistance from colleagues not teaching online; outdated policies; and perceived lack of administrative support (Dumont \& Raggo, 2018). Setting priorities for the provision of instructional designers is critical as chief online officer's report that their use results in increased student performance (Garrett et al., 2019). Failure of online learning initiatives has been attributed to lack of institutional support and limited expertise on the part of leaders (Carlson \& Carnevale, 2001), thus information regarding leadership strategy and its impact on various aspects of online learning success are critically important.

MBA degrees are highly sought, particularly in a market of non-traditional students who have reentered higher education institutions to complete degrees and are balancing careers and families (Roe et al., 2015). The successful implementation of an online MBA program at one institution involved a strategic plan for technology-enhanced learning along with associated resources, including appointing a leader to manage and implement the plan (Ladyshewsky \& Soontiens, 2013). Audits involving course reviews and student feedback encouraged instructors to engage with professional development opportunities to ensure their courses met standards. The steps followed in this case created increased transparency and signaled the importance of online learning. They also exemplify key leadership strategies leading to positive outcomes

As demonstrated in the MBA online program, even though quality assurance recommendations tend to be advisory rather than mandatory (Garrett et al., 2019), they can have a positive impact. The use of Quality Measures in other business education contexts has faced challenges such as a lack of credentialed faculty reviewers and on-going concerns with online testing and online courses in general; however, positive outcomes include increased student retention and graduation, better alignment with accreditation standards, and clear standards for quality online courses (de los Santos \& Zanca, 2018).

Leadership strategies for increasing online learning are fraught with challenges, however. A central one is fear-fear that administrators are motivated by financial gain and that online courses will be viewed as more financially viable than traditional courses, leading to downsizing and the demise of tenure (Nash, 2015). Fear of administratively-mandated enrollment increases can result in faculty decreasing the frequency and kinds of tasks required due to time demands (Dumont \& Raggo, 2018). Others express concern that students view online courses as easy and lack the motivation to be successful without extensive faculty intervention (Shaw, Chanetzky, Burrus \& Walters, 2013). Students are also perceived to lack initiative (Dumont \& Raggo, 2018), awareness of requirements, time commitment, organizational skills (Fetzner, 2013), and self-discipline (Clinefelter \& Magda, 2016). On-going national survey results capturing attitudes toward online learning indicate that faculty view the modality as inferior to traditional learning, yet academic leaders see it as a critical strategy for the future (Allen, Seaman, Lederman, \& Jaschik, 2012; Allen \& Seaman, 2013, 2014).

To address this, the literature represents a preponderance of research on quality assurance including accreditation standards, policies, quality scorecards, and other evaluation instruments (Al Zumor, 2015; Alsaif, \& Clementking, 2014; Baldwin \& Trespalacios, 2017; Budden, \& Budden, 2013; Cabuk, Saye, Ulucay, Melike, \& Cabuk, 2013; Chua \& Lam, 2007; Grace, Weaven, Bodey, Ross, \& Weaven, 2012; Legon, Runyon \& Aman, 2007; Lenert \& Janes, 2017; Marciniak, 2018; Martin, Polly, Jokiaho, \& May, 2017; MarylandOnline, Inc., 2018; Meyer, 2014; Piña \& Bohn, 2015; Scull, Kendrick, Shearer, \& Offerman, 2011; Smith \& Mitry, 2008). The majority (85\%) of chief online officers in one study indicated that quality assurance was in place for at least one of the following areas: online course design, program design, faculty development, support services, and student outcomes (Garrett et al., 2019).

This strand of research has explored how to ensure online courses are high quality and meet consistent standards although traditional courses do not undergo the same scrutiny. However, a perhaps 
unexpected outcome of increasing enrollments in distance learning courses is greater interest in instructional practices and improving teaching and learning across all modes of delivery (McPherson \& Baccow, 2015). Overall, the view is that investing in a design team approach to online course design produces higher quality courses, and subsequently, greater student retention and learning (Garrett et al., 2019). Benchmarks for online degree success are predominantly retention and graduation as well as achievement of program objectives (Garrett et al., 2019).

Institutional leaders must consider both benefits and challenges to online learning. The former have been identified as convenience, efficiency, time, accessibility, dynamic interactions, and creativity while the latter involve access to technology, value and affordability, student self-discipline and motivation, and faculty training, among others (Mbuva, 2014). These factors must be considered in strategic planning at both institutional and program levels. Professional development opportunities for faculty are particularly critical as "online course offerings are being released at a faster rate than current faculty are being trained to deliver quality education in a digital age" (Lenert \& Janes, 2017, p. 1). Faculty must stay current with digital tools, the use of technology-assisted learning applications, and understand how these applications can best contribute to learning (Lenert \& Janes, 2017).

One appeal of online learning for administrators is the ability to collect and monitor a range of metrics related to student success, and for different populations of learners, as well as data related to instructor behaviors (e.g., turn-around of assignments, response time to students, content covered) (McPherson \& Bacow, 2015). These metrics are fairly common in institutions offering only online degrees; however, faculty in traditional higher education institutions would find this level of monitoring highly objectionable. Thus, the planning process must determine what types of data to collect, how, and why and this must be transparent to stakeholders. Certainly, evaluation metrics need to be in place.

In sum, this review has demonstrated key institutional considerations and actions related to planning and strategic direction for distance learning and institutional responsibility to provide related resources and support. The literature does not, however, demonstrate the effectiveness of these strategies on desired outcomes, such as faculty buy-in and participation, online course expansion, or actual student enrollments. In particular, limited information is available about strategies for online learning in schools of business and their impact. Future forecasts clearly indicate that online learning is a critically important aspect of higher education but needs to be more fully embraced across all institutional types (Seaman, Allen, \& Seaman, 2018). Schools of business, offering the highest enrolled degree programs across a number of different countries, must be positioned to set appropriate strategy and implement effective online learning initiatives.

\section{METHODS}

This study involved an online survey of deans of AACSB-accredited business schools to determine their strategies and practices for online learning. The survey was based on a study by Kunz and Cheek (2016), which identified the need for further research on online education in schools of business, specifically its development, current status, and future; and on an annual national survey of chief academic officers about online learning in the U.S. (Seaman et al., 2018). Our survey focused on strategy for online learning and associated challenges and successes. Demographic and enrollment information was also included. The survey was reviewed by multiple individuals prior to administration to determine that the content was valid and relevant.

Contact information for the deans was obtained from the Association to Advance Collegiate Schools of Business (AACSB). The list included 800 AASCB-accredited schools, from which were we able to identify 621 e-mail addresses (474 in the U.S. and 147 international). A total of 414 addresses were usable although some may have been blocked by spam filters. Of these, 121 responses were received and 84 fully completed; 21 of these were from outside the U.S. and represented the following countries: Canada, Australia, New Zealand, Singapore, Hong Kong, Republic of China, Mexico, Chile, Peru, and Lebanon. 


\section{RESULTS}

When asked about the course offerings at their university, deans reported that $61.64 \%$ of their courses were offered online, with $38.36 \%$ reporting they offered online degrees as well. Additionally, the overall mean percentage of students taking at least one online course in the school of business was $28.87 \%$. When asked if they felt that online course enrollments were increasing, the deans reported the following: strongly agree $39.02 \%$, somewhat agree $46.34 \%$, neither agree nor disagree $13.41 \%$, somewhat disagree $1.22 \%$.

To determine if having online degrees predicts the approximate percentage of students taking at least one online course, a regression was run, the results of which were statistically significant in the affirmative, with $\beta=0.51, t(77)=5.20, \mathrm{p}<.001$ and $\mathrm{R}=0.51, \mathrm{R}^{2}=0.26$, Adjusted $\mathrm{R}^{2}=0.25, \mathrm{~F}(1,77)=27.00$, $\mathrm{p}<.0010$. The deans' opinions as to whether online course enrollments were increasing was statistically related to the approximate percentage of students taking at least one online course, with that regression significant in the affirmative, with

$\beta=0.32, t(76)=2.93, \mathrm{p}=0.004$, and $\mathrm{R}=0.32, \mathrm{R}^{2}=0.10$, Adjusted $\mathrm{R}^{2}=0.09, \mathrm{~F}(1,76)=8.60, \mathrm{p}=0.004$. However, the status of the university being public or private, nor being for or non-profit was predictive of students taking at least one online course, with $\mathrm{R}=0.13, \mathrm{R}^{2}=0.017$, Adjusted $\mathrm{R}^{2}=0.00, \mathrm{~F}(2,76)=0.66$, $\mathrm{p}=0.52$.

For the areas of study offered in their online undergraduate degrees, deans reported the following: marketing $14.13 \%$, accounting $14.13 \%$, finance $7.61 \%$, economics $3.26 \%$, management $22.83 \%$, entrepreneurship, 3.26\%, human resources $8.70 \%$, and other $26.09 \%$ (general business, management information systems, business administration, cybersecurity, etc.). In terms of the approximate number of online undergraduate degrees offered by the schools of business, $32.56 \%$ reported offering $1-2,10.47 \%$ offered $3-5$, and $9.3 \%$ offered 5 or more online degrees. Additionally, the number of online degrees the school of business offers predicts the approximate percentage taking at least one online course with $\beta=0.25, t(77)=2.26, \mathrm{p}=0.03$, and $\mathrm{R}=0.25, \mathrm{R}^{2}=0.06$, Adjusted $\mathrm{R}^{2}=0.05, \mathrm{~F}(1,77)=5.11, \mathrm{p}=0.03$.

For online graduate degrees, $34.43 \%$ of deans reported offering $1-2,9.84 \%$ offering $3-5$, with $4.92 \%$ offering 5 or more. The number of graduate programs offered at the institution predicts the approximate percentage taking at least one online course with $\beta=0.36, t(77)=3.39, \mathrm{p}=0.001$, and $\mathrm{R}=0.36, \mathrm{R}^{2}=0.13$, Adjusted $\mathrm{R}^{2}=0.12, \mathrm{~F}(1,77)=11.52, \mathrm{p}=0.001$. Additionally, the graduate areas offered at the institution do predict the approximate percentage taking at least one online course, though only marginally, with $\mathrm{R}=$ $0.50, \mathrm{R}^{2}=0.25$, Adjusted $\mathrm{R}^{2}=0.11, \mathrm{~F}(8,41)=1.74, \mathrm{p}<0.06$, one tailed. Significant predictors include Marketing, $\beta=0.49, t(41)=2.66, \mathrm{p}=0.01$ and Management, $\beta=-0.41, t(41)=-2.19, \mathrm{p}=0.03$. In addition, economics and entrepreneurship were marginally significant with $\beta=0.20, t(41)=-1.41, \mathrm{p}=0.08$, one tailed, and $\beta=-0.33, t(41)=-1.41, \mathrm{p}=0.08$, one tailed, respectively.

The deans were also asked about the support available to business faculty teaching online with the following results: $42.05 \%$ supply instructional designers, $45.64 \%$ give training, and $12.31 \%$ report giving other kinds of support, predominantly technology support. Support available to business faculty teaching online predicts the approximate percentage taking at least one online course with $\mathrm{F}(3,61)=4.91, \mathrm{p}=0.004$, $\mathrm{R}=0.44, \mathrm{R}^{2}=0.19$, Adjusted $\mathrm{R}^{2}=0.15$. However, only the category of "other" support was statistically significant, with $\beta=0.43, t(61)=3.62, \mathrm{p}<.001$.

In terms of instructional designers, $25.77 \%$ were supplied by the business school, $67.01 \%$ were supplied by the institution itself, with $7.22 \%$ coming from another source such as an external partner or outside vender. Who supplied the instructional designers did not predict the approximate percentage of students taking at least one online course, and all provider options (school of business, institution, and other) were nonsignificant.

Regarding training, $28.93 \%$ of deans reported supplying training for online learning directly from the business school itself, with $61.61 \%$ indicating that training is supplied by their institution, and $9.92 \%$ reporting that such training is given by an external entity. However, the source of the training did not statistically significantly predict the approximate percentage of students taking at least one online course in a regression analysis used to explore that possibility. 
In terms of faculty incentives for training, $45.21 \%$ of deans reported that faculty are recognized for completing training to teach online classes with a stipend or other monetary reward, with $24.66 \%$ giving recognition in tenure/promotion. Additionally, 30.14\% reported that recognition comes in the form of some other method (as an expectation or part of the regular workload, in performance reviews, requiring it in order to teach online, a certificate, etc.). However, regression results indicate that recognizing faculty for completing training is not a significant predictor of the approximate percentage of students taking at least one online course.

How training is delivered was reported as follows: online $25.59 \%$, workshop $28.35 \%$, one-on-one $25.59 \%$, informal mentoring $19.29 \%$, other $1.18 \%$ (external entity, etc.). In a regression analysis that was run, the modality of training was not a statistically significant predictor of the approximate percentage of students taking at least one online course.

Lastly, the number of deans reporting on what the training to teach online classes consisted of indicated the following: technology $22.19 \%$, LMS $20.05 \%$, course design $21.12 \%$, pedagogy $20.05 \%$, assessment $15.24 \%$, other $1.34 \%$ (accessibility, video, etc.). When a regression was run to determine if the kind of technology used for training predicted the approximate percentage of students taking at least one online course, the answer was in the affirmative. These positive results showed that $\mathrm{R}=0.46, \mathrm{R}^{2}=$ 0.21 , Adjusted $\mathrm{R}^{2}=0.13$, and $\mathrm{F}(6,60)=2.67, \mathrm{p}=0.02$. However, only the variables LMS, $\beta=0.40, t(60)=$ $2.43, \mathrm{p}=0.02$, and Other, $\beta=0.30, t(60)=2.40, \mathrm{p}=0.02$, were statistically significant, though Technology Tools, $\beta=-0.19, t(60)=-1.32, \mathrm{p}=0.10$, one tailed, and Pedagogical, $\beta=0.20, t(60)=1.41, \mathrm{p}=0.08$, onetailed, were marginally significant.

\section{DISCUSSION AND IMPLICATIONS}

Results of this study determine the type of university, public, private, for-profit, or non-profit did not have any influence in predicting students would take at least one course online. However, offering online degrees was significant in predicting the percentage of students taking online classes. This result would be obvious to many, as students would have to take online courses in order to complete an online degree. The number of online degrees, both undergraduate and graduate offered online also influenced the number of students taking at least one online course. Furthermore, the graduate area of study for these degrees marginally influenced the number of students taking at least one online course. Specifically, marketing and management areas were found to be significant. Additionally, the reported increasing online course enrollments also positively related to the number of students taking courses online.

The results found that only the "other" category of support, predominantly support for technology was significant in predicting the percentage of faculty teaching online. Neither instructional designer support, nor training were significant in predicting the percentage of faculty teaching online. The results did find that training to teach online which was directed toward the learning management system, and technology (other) was significant in predicting the percentage of students taking at least one course online. Specific training on technology tool and pedagogy were marginally influential.

The size of course enrollment impacts both the faculty teaching and the students in the course. While Dumont and Raggo (2018) found the number of students enrolled in the course impacted both the amount of time faculty spent on the course as well as the amount of individual engagement they felt was possible, students were less satisfied in larger courses, even when capped at 40, with the overall course, and instructional interactivity, as well as assessment of their evaluation and progress in the course (Kingma \& Keefe, 2006). Kingma and Keefe (2006) report the optimal class size appears to be 20-29, dependent upon the evaluation metric being used, specifically noting that students' overall evaluation of a course will increase until enrollment reaches 23, and then it declines. Despite what one might assume, faculty with more online teaching experience do not necessarily receive higher course evaluations. The authors conclude, that while universities may see large classrooms, including online courses as a necessity to cover costs and deliver revenues, students may perceive lower quality in such offerings.

Research which investigated the perceptions of business students' online experience found students take online courses as a matter of convenience and lack of offering in the traditional format for a specific 
course (Kuzma, Kuzma, \& Thiewes, 2015). Slightly less than half (43\%) chose an online course because of scheduling conflicts, and $86 \%$ of the students indicated overall convenience was the reason for taking a course online. Seventy-eight percent liked the convenience of not having to travel to campus, and $71 \%$ chose online courses because they did not conflict with work schedules. Additionally, about one-third of the students perceived a required online course was easier, although there did not seem to be a strong consensus across majors or types of courses. Students did however agree that online courses make cheating easier.

The results of the current study would support findings from the literature review, that faculty training/support and overall institutional support for online courses and programs positively influence student participation in online instruction and degrees. Furthermore, it appears that the convenience of access via online instruction fits into the current lifestyle and professional goals of today's population. Thus, it appears as though online learning is here to stay and has become a permanent part of the higher education culture.

\section{CONCLUSION}

Education is a "partnership between [higher education providers] and students with the goal of providing accessible yet manageable learning opportunities for a wide range of people" (Higher Education Academy, 2015, p. 4). This study has shown that schools of business are offering both courses and degree programs online, and it appears that the more online offerings made available, the more likely students are to take advantage of the educational opportunity. While the area of study for undergraduate business programs does not influence enrollments in online courses, the area of study in graduate programs does, with marketing and management more likely to drive enrollment for graduate students. These results parallel findings in the CHLOE Report (Garrett et al., 2019) that was sponsored by Quality Matters and Eduventures surveyed chief online officers in higher education noted online learning is becoming mainstream in U.S. higher education, and as such practices, policies and impact should be tracked regularly. Others observe that online education has become mainstream rather than a method needing justification (Kentnor, 2015), and that it may be an improvement or even a replacement for traditional face-to-face delivery (Arasaratnam-Smith \& Northcote, 2017).

Researchers and scholars have expressed perspectives about the future of online learning in higher education. It is generally acknowledged that "despite the current drawbacks, online education is still the best prospect for the future provided the barriers of faculty assessment and course design are addressed" (Nash, 2015, p. 80). The initial era of online education was aimed at access while the next era is aimed at improving educational quality, particularly the way knowledge is "transmitted, preserved, and generated" (Sener, 2012, p. 124). Overall, online learning has created an intense focus on quality and effectiveness across all delivery modalities (McPherson \& Bacow, 2015). Richard Levin, former president of Yale and current Chief Executive Officer of Coursera, stated, "In 10 or 20 years, when we judge the great universities, it will not just be on their research but on the reach of their teaching" (Kolowich, 2014). The results of the current survey and study would support the need of today's higher education institutions to employ online education as a means to meet the needs of current and future potential students. 


\section{REFERENCES}

Albert, 1. J., \& Johnson, C. S. (2011). Socioeconomic status-and gender-based differences in students' perceptions of e-learning systems. Decision Sciences, 9(3), 421-436.

Allen, E., \& Seaman, J. (2013). Changing course: Ten years of tracking online education in the United States. The Sloan Consortium. Retrieved from http://www.onlinelearningSurvey.com/reports/changingcourse.pdf

Allen, E., \& Seaman, J. (2014). Grade change: Tracking online education in the United States. The Sloan Consortium. Retrieved from http://www.onlinelearningsurvey.com/reports/gradechange.pdf

Allen, E., Seaman, J. Lederman, D., \& Jaschik, S. (2012). Conflicted: Faculty and online Education, 2012. The Sloan Consortium. Retrieved from http://www.insidehighered.Com/sites/default/server_files/survey/conflicted.html

Alsaif, F., \& Clementking, A. (2014). E-learning quality assurance practices and benchmarks in higher education. In J. Viteli \& M. Leikomaa (Eds.), Proceedings of EdMedia 2014--World Conference on Educational Media and Technology (pp. 1072-1078). Tampere, Finland: Association for the Advancement of Computing in Education (AACE). Retrieved from https://www.learntechlib.org/primary/p/147625/.

Al Zumor, A. W. Q. (2015). Quality Matters rubric potential for enhancing online foreign language education. International Education Studies, 8(4), 173-178.

Andrade, M. S. (2016). Distance learning: Making connections through social networking. In C. Bernadas $\&$ D. Minchella (Ed.), Proceedings of the $3^{\text {rd }}$ Annual European Conference on Social Media (pp. 9-18), Caen, France.

Arasaratnam-Smith, L. A., \& Northcote, M. (2017). Community in online higher education: Challenges and opportunities. Electronic Journal of e-Learning, 15(2), 188-198.

Australian Bureau of Statistics. (2017, October 23). Australians pursuing higher education in record numbers. Retrieved from http://www.abs.gov.au/AUSSTATS/abs@.nsf/mediareleasesbytitle/1533FE5A8541D66CCA258 1BF00362D1D?OpenDocument

Baldwin, S. J., \& Trespalacios, J. (2017). Evaluation instruments and good practices in online education. Online Learning, 21(2).

Budden, C. B., \& Budden, M. C. (2013). A look at an implementation of the Quality Matters program in a collegiate environment: Benefits and challenges. Contemporary Issues in Education Research, 6(4), 381-384.

Cabuk A., Saye, N., Ulucay, D. Melike, T., \& Cabuk, A. (2013). Accreditation of online and distance learning programs: Online GIS education program experience. Turkish Online Journal of Distance Education, 14(1), 231-244.

Carlson, S., \& Carnevale, D. (2001). Debating the demise of NYUonline. The Chronicle of Higher Education, A31. Retrieved from http://chronicle.com/free/v48 / i16/16a03101.html

Carnevale, A. P., Smith, N., Melton, M., \& Price, E. W. (2015). Learning while earning: The new normal. Georgetown University: Center on Education and the Workforce. Retrieved from https://1gyhoq479ufd3yna29x7ubjn-wpengine.netdna-ssl.com/wp-content/uploads/WorkingLearners-Report.pdf

Chua, A., \& Lam, W. (2007). Quality assurance in online education: The Universitas 21 global approach. British Journal of Educational Technology, 38(1), 133-152. doi: 10.1111/j.14678535.2006.00652.x

Clinefelter, D. L., \& Magda, A. J. (2016). Online learning at private colleges and universities 2016: A survey of chief academic officers. Louisville, KY: The Learning House.

Community College Research Center. (2013). Creating an effective online environment. Teachers College, Columbia University. Retrieved from http://ccrc.tc.columbiaEdu/media/k2/attachments/creating-effectiveonline-environment.pdf

Côté, J., \& Allahar, A. L. (2011). Lowering higher education: The rise of corporate universities and the fall of liberal education. Toronto, Canada: The University of Toronto Press. 
de los Santos, E., \& Zanca, N. A. (2018). Transitioning to online: A SWOT analysis by first time online business faculty. The e-Journal of Business Education \& Scholarship of Teaching, 12(3), 69-84.

Dumont, G., \& Raggo, P. (2018). Faculty perspectives about distance teaching in the virtual classroom, The Journal of Nonprofit Education and Leadership, 8(1) 41-61.

Evans, C., Rees, G., Taylor, C., \& Wright, C. (2017). Widening access to higher education: The reproduction of university hierarchies through policy enactment. Journal of Education Policy. DOI: $10.1080 / 02680939.2017 .1390165$

Fetzner, M. (2013). What do unsuccessful online students want us to know? Online Learning, 17(1). doi:10.24059/olj.v17i1.319

Fredericksen, E. E. (2017). A national study of online learning leaders in US higher education. Online Learning, 21(2).

Garrett, R., Legon, R., \& Fredericksen, E. E. (2019). CHLOE 3 Behind the numbers: The changing landscape of online education 2019. Retrieved from https:/www.qualitymatters.org/qaresources/resource-center/articles-resources/CHLOE-3-report-2019

Grace, D., Weaven, S., Bodey, K., Ross, M., \& Weaven, K. (2012). Putting student evaluations into perspective: The course experience quality and satisfaction model (CEQS). Studies in Educational Evaluation, 38(2), 35-43. doi:10.1016/j.stueduc.2012.05.001

Higher Education Statistics Agency. (2018). Higher education student statistics: UK, 2016/17 - Subjects studied. Retrieved from https://www.hesa.ac.uk/news/11-01-2018/sfr247-higher-educationstudent-statistics/subjects

Higher Education Academy. (2015). Flexible learning in higher education. Retrieved from https://www.heacademy.ac.uk/system/files/downloads/higher_education_academy__flexible_learning_framework___210416.pdf

Institute for Higher Education Policy. (2000). Quality on the line: Benchmarks for success in internetbased distance education. National Education Association, 1-45. Retrieved from http://www.nea.org/assets/docs/HE/QualityOnTheLine.pdf

Kentnor, H. E. (2015). Distance education and the evolution of online learning in the United States. Curriculum \& Teaching Dialogue, 17(1/2), 21-34.

Kingma, B., \& Keefe, S. (2006). An analysis of the virtual classroom: Does size matter? Do residencies make a difference? Should you hire that instructional designer? Journal of Education for Library \& Information Science, 47(2), 127-143.

Kolowich, S. (2014). Coursera chief: Reach of teaching will define great universities. The Chronicle of Higher Education. Retrieved from http://chronicle.com/blogs/wiredcampus/ coursera-chief-reachof-teaching-will-defi ne-great-universities/53445

Kunz, M. B., \& Cheek, R. G. (2016). How AACSB-accredited business schools assure quality online education. Academy of Business Journal, 1(2), 105-115.

Kuzma, A., Kuzma, J., \& Thiewes, H. (2015). Business student attitudes, experience, and satisfaction with online courses. American Journal of Business Education (Online), 8(2), 121.

Ladyshewsky, R., \& Soontiens, W. (2013). Managing the online learning revolution in an MBA course: Quality assurance through strategic development. Working Papers 2018/26, Maastricht School of Management. Maastricht: Netherlands. Retrieved from https://ideas.repec.org/p/msm/wpaper/2013-26.html

Legon, R., Runyon, J., \& Aman, R. (2007, October). The impact of "Quality Matters" standards on courses: Research opportunities and results. Paper presented at the13th International Sloan-C Conference on Online Learning, Orlando, FL.

Lenert, K. A., \& Janes, D. P. (2017). The incorporation of quality attributes into online course design in higher education. International Journal of E-Learning \& Distance Education, 32(1), 1-14.

Retrieved from https://files.eric.ed.gov/fulltext/EJ1146391.pdf

Lumina Foundation. (n. d.). Today's reality. Retrieved from https://www.luminafoundation.org/todaysstudent-statistics

56 Journal of Higher Education Theory and Practice Vol. 19(5) 2019 
Ma, J., Pender, M., \& Welch, M. (2016). Education pays 2016. The benefits of higher educaiton for individuals and society. College Board. Retrieved from

https://trends.collegeboard.org/sites/default/files/education-pays-2016-full-report.pdf

Marciniak, R. (2018). Quality assurance for online higher education programmes: Design and validation of an integrative assessment model applicable to Spanish universities. International Review of Research in Open \& Distance Learning, 19(2), 126-154. Retrieved from http://www.irrodl.org/index.php/irrodl/article/view/3443/4622

Martin, F., Polly, D., Jokiaho, A., \& May, B. (2017). Global standards for enhancing quality in online learning. Quarterly Review of Distance Education, 18(2), 1-10.

MarylandOnline, Inc. (2018). Specific review standards from the QM higher education rubric, Sixth Edition. Retrieved from

https://www.qualitymatters.org/sites/default/files/PDFs/StandardsfromtheQMHigherEducationRu bric.pdf

Mbuva, J. M. (2014). Online education: Progress and prospects. Journal of Business and Educational Leadership, 5(1), 91-101.

McPherson, M. S., \& Bacow, L. S. (2015). Online higher education: Beyond the hype cycle. Journal of Economic Perspectives, 29(4), 135-154. doi: 10.1257/jep.29.4.135

Meyer, K. A. (2014). Quality in distance education: Focus on on-line learning. ASHE-ERIC Higher Education Report. Jossey-Bass Higher and Adult Education Series.

Nash, J. A. (2015). Future of online education in crisis: A call to action. Turkish Online Journal of Educational Technology, 14(2), 80-88.

National Center for Educational Statistics. (2018). Fast facts. Most popular majors. Retrieved from https://nces.ed.gov/fastfacts/display.asp?id=37

Ossiannilsson, E., Williams, K., Camilleri, A., \& Brown, M. (2015). Quality models in online and open education around the globe. State of the art and recommendations. Oslo: International Council for Open and Distance Education. Retrieved from https://www.pedocs.de/volltexte/2015/10879/pdf/Ossiannilsson_et_al_2015_Qualitymodels.pdf

Picciano, A. G., Seaman, J., \& Allen, I. E. (2010). Educational transformation through online learning: To be or not to be. Journal of Asynchronous Learning Networks, 14(4), 17-35. Retrieved from https://files.eric.ed.gov/fulltext/EJ909909.pdf

Piña, A. A., \& Bohn, L. (2015). Integrating accreditation guidelines and quality scorecard for evaluating online programs. Distance Learning, 12(4), 1-6.

Roe, C., Toma, A. G., Yallapragada, R., \& Mohan R. (2015). Innovation in business education: Developing a high quality online MBA. American Journal of Business Education, 8(2), 169-176.

Seaman, J. E., Allen, I. E., \& Seaman, J. (2018). Grade increase: Tracking distance education in the United States. Babson Survey Research Group. Retrieved from http://www.onlinelearningsurvey.com/highered.html

Scull, W. R., Kendrick, D., Shearer, R., \& Offerman, D. (2011). The landscape of quality assurance in distance education. Continuing Higher Education Review, 75, 138-149. Retrieved from https://files.eric.ed.gov/fulltext/EJ967815.pdf

Sener, J. (2012). The seven futures of American education: Improving learning and teaching in a screen captured world. North Charleston, SC: CreateSpace.

Shaw, M., Chametzky, B., Burrus, S.W. \& Walters, K. J. (2013). An evaluation of student outcomes by course duration in online higher education. Online Journal of Distance Learning Administration, 16(4). Retrieved from http://www.westga.edu/ distance/ojdla/Winter164/shaw_chametzky_burrus_walters164.html

Smith, D. E., \& Mitry, D. J. (2008). Investigation of higher education: The real costs and quality of online programs. Journal of Education for Business, 83(3), 147-152.

Statistica. (2018). Number of students enrolled in postsecondary institutions in Canada in 2015/16, by field of study. Retrieved from https://www.statista.com/statistics/447843/postsecondaryenrollments-in-canada-by-instructional-program/ 